\title{
Operation of solid oxide fuel cells with alternative hydrogen carriers
}

\author{
Hagen, Anke; Langnickel, Hendrik; Sun, Xiufu
}

Published in:

International Journal of Hydrogen Energy

Link to article, DOI:

10.1016/j.ijhydene.2019.05.065

Publication date:

2019

Document Version

Peer reviewed version

Link back to DTU Orbit

Citation (APA):

Hagen, A., Langnickel, H., \& Sun, X. (2019). Operation of solid oxide fuel cells with alternative hydrogen carriers. International Journal of Hydrogen Energy, 44(33), 18382-18392. https://doi.org/10.1016/j.ijhydene.2019.05.065

\section{General rights}

Copyright and moral rights for the publications made accessible in the public portal are retained by the authors and/or other copyright owners and it is a condition of accessing publications that users recognise and abide by the legal requirements associated with these rights.

- Users may download and print one copy of any publication from the public portal for the purpose of private study or research.

- You may not further distribute the material or use it for any profit-making activity or commercial gain

- You may freely distribute the URL identifying the publication in the public portal

If you believe that this document breaches copyright please contact us providing details, and we will remove access to the work immediately and investigate your claim. 


\title{
Operation of Solid Oxide Fuel Cells with Alternative Hydrogen Carriers
}

\author{
Anke Hagen, Hendrik Langnickel, Xiufu Sun \\ DTU Energy, Frederiksborgvej 399, 4000 Roskilde, Denmark \\ *anke@dtu.dk, +45 46775884, corresponding author
}

\begin{abstract}
Future electricity production will use fossil-free sources with zero $\mathrm{CO}_{2}$ emission or closed carbon cycle technologies based on renewable sources. While hydrogen is considered a key energy source, its production at present time relies heavily on fossil fuels. Furthermore, distribution and storage are not well established and require substantial investments. This is a strong motivation to identify alternative, safe, high power density hydrogen carriers, where existing logistics and infrastructure can be utilized. In this contribution, ammonia and biogas are considered for high-efficient electricity production in solid oxide fuel cells (SOFCs). It is demonstrated that the properties and operating conditions of SOFC allow for direct use of these fuels, with fuel pretreatment inside the SOFC anode. The high efficient electricity production using pure ammonia or real biogas was successfully proven on stateof-the-art SOFCs. Even without optimization of operating parameters, electrical efficiencies of 40-50\% and high and stable power output were demonstrated.
\end{abstract}

\section{Keywords}

SOFC, hydrogen carrier, ammonia, biogas, efficiency

\section{Introduction}

Fuel cells convert the chemical energy contained in a fuel into electricity and heat with high electrical efficiencies, which are not limited by the Carnot cycle, as conventional combustion technologies [1]. Hydrogen is considered an important fuel for the future [2]. At present, hydrogen is mainly obtained from fossil fuels through reforming, partial oxidation or gasification (see review articles in references therein [2, 3]). Future concepts will involve electrolysis of steam using electricity from renewable sources and usage of alternative feed stocks such as biomass [2, 3, 4]. The current lack of a wide spread hydrogen production based on renewable technologies, of storage and distribution infrastructures, the low energy density per weight/volume, and safety concerns are motivating factors to investigate usability of alternative hydrogen carriers, both, shortterm and long-term options.

Among the different existing fuel cell types, solid oxide fuel cells (SOFC) stand out with the advantageous feature of fuel flexibility, i.e. they are not limited to a single fuel such as pure hydrogen. This ability to utilize for example carbon containing gases or liquids make SOFC suitable for a large variety of applications making use of the existing fuel logistics and 
infrastructure, including remote locations. They are an attractive option for the transition periods when energy technologies are moving towards renewable energy systems and for the future energy systems, which will be based on renewables, solely.

The European Union has the goal to significantly reduce greenhouse gas emissions by $40 \%$ in 2030 , and by $80 \%$ to $95 \%$ in 2050 , both as compared to 1990 levels $[5,6]$. The fuel flexibility of SOFC allows for even more reduction of the $\mathrm{CO}_{2}$ footprint of the fuel or for a closed carbon cycle. First demonstration and commercial units based on SOFC typically use natural gas for stationary applications $[7,8]$. Due to the high electrical efficiencies, the needed amounts of the fossil fuel natural gas is reduced as well as greenhouse gas emissions as compared to combustion of natural gas. The highly efficient usage of natural gas is only one step for reducing emission of $\mathrm{CO}_{2}$, but far from sufficient. Fuels with a lower $\mathrm{CO}_{2}$ footprint than natural gas, with a closed carbon cycle, or carbon-free fuels need to be considered. Biogas and ammonia are two examples for attractive fuels solving such challenges. State-of-the-art (SoA) SOFC anodes are composed of a composite between nickel and yttria stabilized zirconia (Ni/YSZ cermet), nickel being a catalyst, which can similar to large-scale catalytic reforming processes $[9,10]$ - reform hydrocarbons with steam or $\mathrm{CO}_{2}$ within the SOFC anode [11,12]. This functionality can also be utilized when using biogas $[13,14,15,16]$ as an available fuel in a fossil-free energy scenario. The catalytic activity of the SOFC anode is not restricted to the reforming of hydrocarbons. In fact, it is also active for the cracking of ammonia, another interesting fuel. Previous preliminary studies have shown that ammonia can be used as fuel in SoA SOFCs $[17,18,19$, 20].

The article presents the opportunities of using alternative hydrogen carriers like biogas and ammonia as SOFC fuels in the light of physical properties, availability, and achievable electrical efficiencies. The applicability of these fuels will be demonstrated through tests at SOFC cell level.

\section{Availability and physical/chemical properties of ammonia and biogas}

\section{Ammonia}

Ammonia is among the top synthetic products worldwide and produced in hundreds of millions of tons per year. It is an important intermediate for the production of fertilizers, polymers, pharmaceuticals and other chemicals. Millions of tons of ammonia are stored, transported, and handled every year with a well-established infra structure, safety procedures, and a proven safety history $[21,22,23]$. While at present day, hydrogen for the production of ammonia origins from fossil sources, intensive effort is devoted to identify routes for fossil-free (hydrogen) ammonia (see for example a recent review [24]), mainly based on electrolysis. The electricity may come from renewable sources such as wind or solar power. Ammonia is not corrosive, not explosive nor highly flammable, and it can be stored at moderate pressures (typical gas cylinder pressures are 8 bar). Among other favourable properties in regard to use as a fuel, the high power density per weight and volume can be mentioned (values for conventional fuels and hydrogen see Table 1). The potential of ammonia as hydrogen carrier was recently reviewed with the focus on a later re-use as hydrogen [25]. In the present context, the potential of direct use as ammonia in an SOFC is discussed. 
Table 1 Energy densities of conventional and potential alternative fuels

\begin{tabular}{|l|l|l|}
\hline Fuel & Energy density & Reference \\
\hline Ammonia HHV & $22.5 \mathrm{MJ} / \mathrm{kg}$ & {$[26]$} \\
\hline Ammonia & $11.5 \mathrm{MJ} / \mathrm{L}$ & {$[26]$} \\
\hline $\begin{array}{l}\text { Compressed } \mathrm{H}_{2} \text { at } 690 \\
\text { bar and } 15^{\circ} \mathrm{C}\end{array}$ & $4.5 \mathrm{MJ} / \mathrm{L}$ & {$[26]$} \\
\hline Gasoline & & {$[26]$} \\
\hline Diesel & $46.4 \mathrm{MJ} / \mathrm{kg} / 34.2 \mathrm{MJ} / \mathrm{L}$ & {$[26]$} \\
\hline Natural gas $/$ methane & $48 \mathrm{MJ} / \mathrm{kg} / 35.8 \mathrm{MJ} / \mathrm{L}$ & {$[26]$} \\
\hline
\end{tabular}

Also for use as fuel in an SOFC, ammonia has to be cracked into hydrogen and nitrogen (see Equation 1), if hydrogen is the species to be oxidized in the SOFC. The difference to a re-use as hydrogen is that such a cracking can occur inside the SOFC (see later discussion). From a thermodynamic view, this reaction progresses at the typical operating temperature of SOFCs. The commercial software FactSage was used for all thermodynamic calculations [27]. Figure 1 shows the equilibrium compositions at temperatures between 200 and 1000 ${ }^{\circ} \mathrm{C}$. The decomposition of ammonia into nitrogen and hydrogen increases with increasing temperature. Already from $400{ }^{\circ} \mathrm{C}$, this decomposition is nearly complete. When approaching typical SOFC operating temperatures of 750 to $850^{\circ} \mathrm{C}$, only ppm levels of ammonia are left in the thermodynamic equilibrium (only $100 \mathrm{ppm}$ ammonia at $850^{\circ} \mathrm{C}$ (see Figure 1). The decomposition is endothermic and can thus be favourably integrated with the exothermal electrochemical reaction in the SOFC to boost the overall system efficiency.

$\begin{array}{lll}\text { Equation } 1 & 2 N H & \mathrm{~N} H(298 \mathrm{~K})=92 \mathrm{KJ} / \mathrm{mol}[28]\end{array}$ 


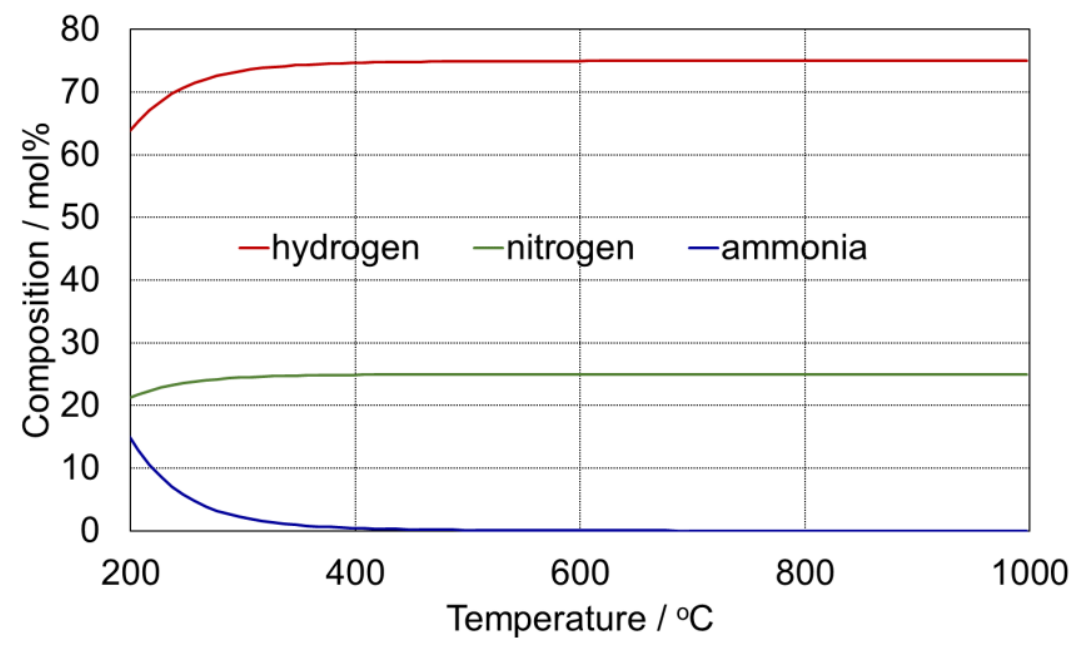

Figure 1 Thermodynamic equilibrium of the ammonia decomposition, calculated using the commercial software FactSage (Equation 1).

Further, the kinetics of ammonia decomposition has to be considered. The SOFC operating temperatures of $750-850{ }^{\circ} \mathrm{C}$ are in favour of a fast reaction. SoA SOFC anodes consist of $\mathrm{Ni}$ /YSZ cermets, which can act as a cracking catalyst. In order to investigate the cracking activity of SoA SOFC anodes, the gas composition leaving the SoA SOFC when introducing pure ammonia or $\mathrm{H}_{2} / \mathrm{N}_{2}$ at the inlet was analysed with a mass spectrometer. The results are shown in Figure 2. First, a mixture of hydrogen and nitrogen with a ratio of 3/1 was led to the SOFC and the expected signals measured at the outlet. The columns corresponding to the mass spectrometer signal of hydrogen and nitrogen have the expected intensities of 3/1. Afterwards, the inlet gas was changed to pure ammonia and the mass spectrometer signal intensities were measured at the outlet. No signal for ammonia was measured, which indicates that ammonia indeed was completely cracked at the conditions of $850^{\circ} \mathrm{C}$ and the used SOFC generation at open circuit voltage (OCV). Under OCV, the anode acts as a pure catalyst, i.e. no electricity is produced. This was also confirmed by the mass spectrometer signals for hydrogen and nitrogen, which show the expected intensity ratio of 3/1 (see Figure 2). Analysing the inlet gas composition just before entering the SOFC anode compartment, ammonia was still detected, which proves that the cracking happens mainly at the catalytic sites inside the SOFC anode and not in the gas pipes leading to the SOFC. Furthermore, no formation of $\mathrm{NO}, \mathrm{NO}_{2}$, or $\mathrm{N}_{2} \mathrm{O}$ was observed by following the respective mass signals, i.e. no toxic $\mathrm{NO}_{\mathrm{x}}$ are formed from ammonia under the applied conditions - in contrast to conventional combustion. 


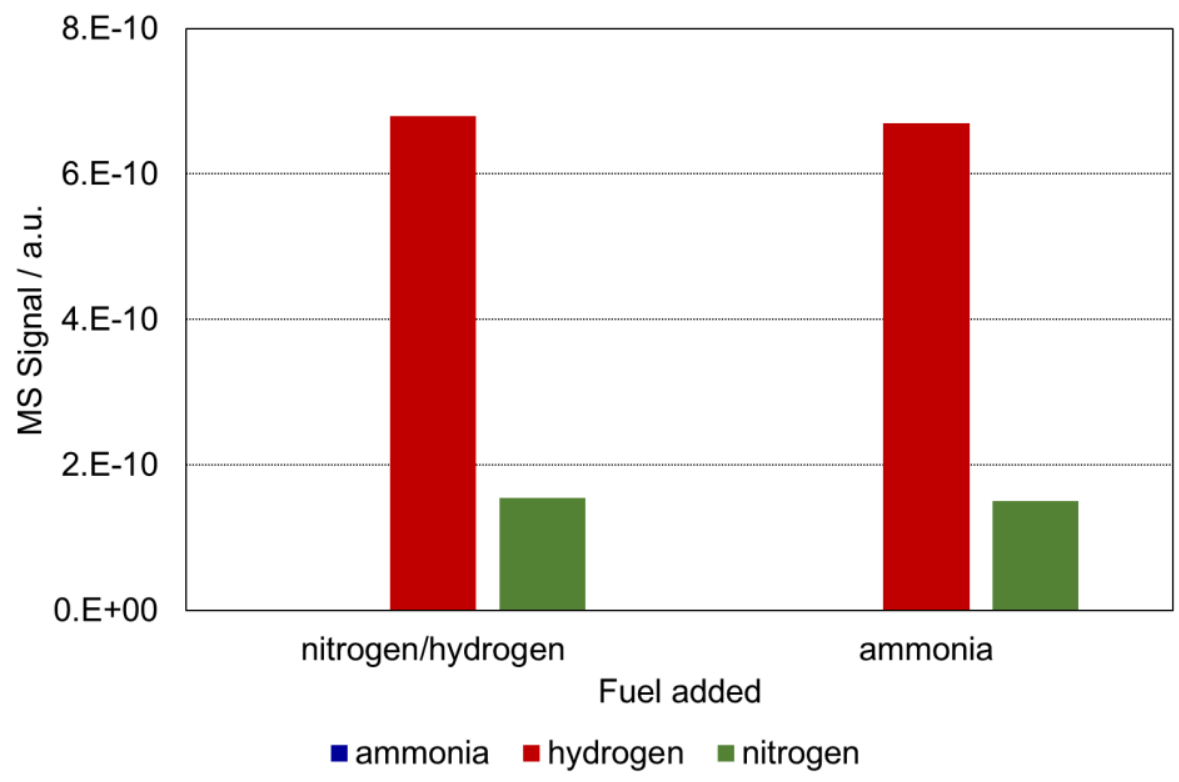

Figure 2 Mass spectrometer signal for $\mathrm{NH}_{3}$ (mass number 17), $\mathrm{H}_{2}$ (mass number 2), and $\mathrm{N}_{2}$ (mass number 28) when leading either a mixture of $\mathrm{H}_{2}+\mathrm{N}_{2}$ with a ratio of $3 / 1$ or $\mathrm{NH}_{3}$ to the $\mathrm{SOFC}$ at $850^{\circ} \mathrm{C}$, analysed at the SOFC outlet.

The thus formed hydrogen can react in the SOFC to form steam as the only product (see Equation 2 and Equation 3 for the overall SOFC reaction). Thus, no $\mathrm{CO}_{2}$ is emitted during this process, which can be considered advantageous when aiming at zero emission applications. In other words, the SOFC allows for electricity production with no local $\mathrm{CO}_{2}$ emission with ammonia fuel, in the same way as when using hydrogen.

\section{Equation 2}

Equation 3

\section{Biogas}

Biogas is the product of anaerobic digestion of organic matter, for example plants, manure, sewage sludge, and organic wastes from industry and households. It is mainly composed of methane and $\mathrm{CO}_{2}$ - both are strong greenhouse gases - and is produced at large scale throughout Europe and worldwide from different biomass sources. The methane can be considered a sustainable energy carrier. In 2016 the total electricity production from biogas was significant 62.5 TWh in the European Union [29]. Further increase is projected for the future [30]. As the present-day technology is mainly based on combustion, the energy content of biogas is not at all used most efficiently. Furthermore, not all available biogas can be used for combustion and the energy content is thus wasted, particularly for biogas compositions with low heating value. In those cases even the addition of fossil fuels like natural oil or gas is employed in a combustion process. 
Wastewater treatment plants and landfills represent the largest share of biogas sources. Biogas from landfills had a share of around $17-21 \%$ of the total biogas production of the European Union and is thus a significant energy source [29, 31]. It is an attractive biogas option because the production does not require investments in treatment plants and the running costs, as it is the case for wastewater treatment. Landfills store human leftovers that have been stripped for recyclable, usable components (for example for recycling or combustion in dedicated power plants). Over time, at the ca. 30 year scale, the waste is naturally evolving biogas. In order to protect the environment from emission of gasses or liquids into the surrounding environment, these landfill sites are well isolated in European countries. The naturally evolving biogas is collected in pipes and can be used in combustion engines. Over time, the composition of $\mathrm{CO}_{2}$ and $\mathrm{CH}_{4}$ in this biogas changes; the content decreases, which requires frequent substitution of combustion engines tailored for the actual composition. Eventually, the heating values becomes too low for direct combustion and the energy content in the biogas is wasted or costly fossil fuels have to be added. On the other hand, waste deposition sites are a worldwide challenge because they are in some regions left open to the air, thereby emitting substantial amounts of greenhouse gasses, for example in Asian countries. This poses an environmental threat and wastes a significant energy resource.

The raw biogas contains various impurities at concentration levels that usually need to be lowered to increase durability of any equipment that utilizes biogas, for example electrical generators. Examples of biogas compositions from different sources are given in Table 2. Of all contaminants in biogas, the presence of sulphur, siloxanes and halogenated compounds are most harmful to SOFC and other exploitation technologies.

Table 2 Examples of biogas compositions from different biogas plants [32]

\begin{tabular}{|l|c|c|c|c|c|}
\hline \multirow{2}{*}{ Composition } & \multicolumn{3}{|c|}{ Biogas } \\
\cline { 2 - 6 } & natural gas & waste water & food waste & $\begin{array}{c}\text { animal } \\
\text { waste }\end{array}$ & landfill \\
\hline methane (vol\%) & $80-100$ & $50-60$ & $50-70$ & $45-60$ & $40-55$ \\
\hline carbon dioxide (vol\%) & $<3$ & $30-40$ & $25-45$ & $35-60$ & $35-50$ \\
\hline nitrogen (vol\%) & $<3$ & $<4$ & $<4$ & $<4$ & $<20$ \\
\hline oxygen (vol\%) & $<0.2$ & $<1$ & $<1$ & $<1$ & $<2$ \\
\hline $\mathrm{H}_{2} \mathrm{~S}$ (ppm) & $<0.1$ & $<400$ & $<10000$ & $<300$ & $<200$ \\
\hline non $\mathrm{H}_{2} \mathrm{~S}$ sulphur (ppm) & $<10$ & $<1$ & $<1000$ & $<30$ & $<30$ \\
\hline halogens (ppm) & $<0.1$ & $<0.2$ & $<0.2$ & $<0.2$ & $<100$ \\
\hline moisture (\%) & $<0.02$ & $\sim 3$ & $\sim 3$ & $\sim 3$ & $\sim 3$ \\
\hline
\end{tabular}

${ }^{*} \mathrm{H}_{2} \mathrm{~S}$ removed during the processing step 
As for all hydrocarbons to be processed at elevated temperatures, the thermodynamically favoured formation of carbon has to be considered as function of temperature. In Figure 3, the carbon formation is shown as function of carbon/oxygen/hydrogen composition and of temperature (lines with different colours). From a thermodynamic point of view, carbon is formed in all those compositions of $\mathrm{C} / \mathrm{O} / \mathrm{H}$, which lie above the lines for a specific temperature. This so-called carbon formation window decreases with increasing temperature. The two main factors that determine carbon formation of any gas composition containing $\mathrm{C}, \mathrm{O}$, and $\mathrm{H}$ are thus the temperature and the content of oxygen and hydrogen. Carbon formation decreases with increasing $\mathrm{H}$ and $\mathrm{O}$ in the compounds. The two symbols in Figure 3 mark two specific cases: methane (natural gas) and a biogas composition of $\mathrm{CH}_{4}$ to $\mathrm{CO}_{2}$ of 1:1 as example for a typical biogas. Clearly, carbon formation is a risk with the given compositions. This risk is reduced by adding hydrogen/oxygen containing reactants such as steam or $\mathrm{CO}_{2}$ - called reforming agents - to natural gas or biogas. Furthermore, even though thermodynamic calculations (as shown in Figure 3) predict the limit for the carbon formation window, the situation can be different in real SOFC cells and stacks, due to local gradients of temperature or gas composition. Therefore, excess of reforming agents is always provided, i.e. more oxygen/hydrogen is added than theoretically needed according to Figure 3 .

In order to leave the thermodynamic carbon formation window, the reforming agents $\mathrm{CO}_{2}$ (dry reforming) or $\mathrm{H}_{2} \mathrm{O}$ (steam reforming) are added as shown in Equation 4 and Equation 5 , respectively. As mentioned, the catalytic properties of SoA SOFC anodes, which contain nickel, should allow for these reforming reactions to proceed internally in the SOFC.

Equation 4

Equation 5

$$
\mathrm{CH}_{4}+\mathrm{CO}_{2} \Leftrightarrow 2 \mathrm{CO}+2 \mathrm{H}_{2}
$$

$$
\mathrm{CH}_{4}+\mathrm{H}_{2} \mathrm{O} \Leftrightarrow \mathrm{CO}+3 \mathrm{H}_{2}
$$

$\Delta H(298 \mathrm{~K})=247.3 \mathrm{KJ} / \mathrm{mol}$

$\Delta H=(298 \mathrm{~K})=206 \mathrm{KJ} / \mathrm{mol}$ 


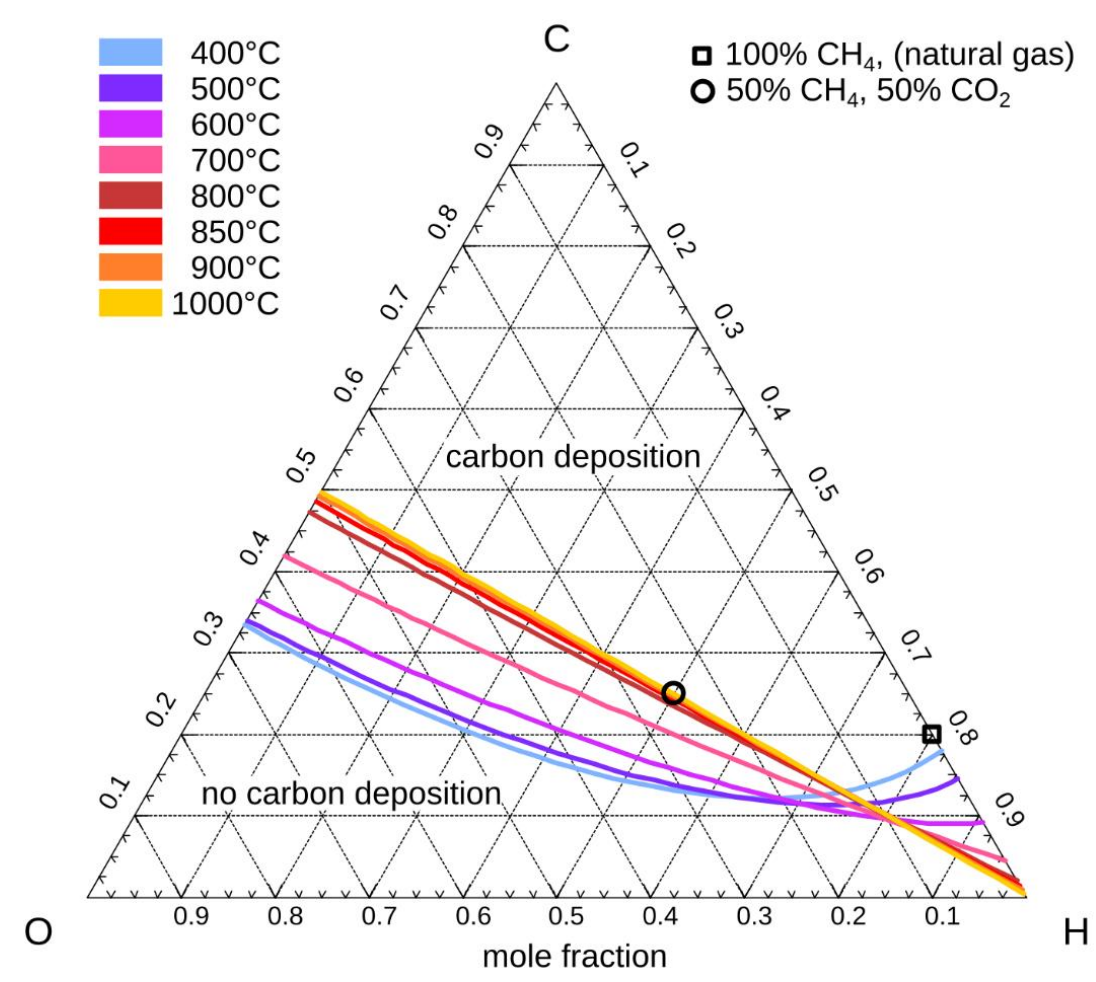

Figure 3 Thermodynamics of carbon formation at different temperatures including the biogas mixture $50 \% \mathrm{CH}_{4}$ plus $50 \% \mathrm{CO}_{2}$ and natural gas $100 \% \mathrm{CH}_{4}$. Calculations were done using the program FactSage.

The $\mathrm{CO}$ and $\mathrm{H}_{2}$ mixtures formed through the reforming can react at the SOFC anode according to Equation 2 and Equation 6, mainly hydrogen is the actually reacting species, while CO mainly reacts through the catalytic water gas shift reaction (Equation 8). This gives the overall oxidation reactions shown in Equation 3 and Equation 7.

\section{Equation 6}

Equation 7

Equation 8

Steam reforming (Equation 5) is the currently most used concept in relation of SOFC, because it is relevant for use of natural gas, having $\mathrm{CH}_{4}$ as the main constituent, for example in combined heat and power (CHP) applications [33]. On the other hand, dry reforming (Equation 4) has significant advantages. Biogas inherently contains the reforming agent $\mathrm{CO}_{2}$, which will simplify the system layout and thus reduce system costs, as steam generation is not needed. Apart from the advantage of already having the reforming agent $\mathrm{CO}_{2}$ in the biogas, dry reforming seems also attractive for improving the impurity tolerance of SoA SOFC anodes. Catalytic studies on SoA anodes indicated that the 
presence of $\mathrm{CO}_{2}$ can mitigate the sulphur poisoning effect on the methane reforming reaction [34]. This finding was confirmed at SOFC cell level in the presence of sulphur impurities and typical biogas compositions [35]. The observed degradation of the power output under steam reforming conditions was even stopped when using $\mathrm{CO}_{2}$ as reforming agent instead of steam [15].

Both reforming reactions are endothermal and can therefore be integrated with the exothermal fuel cell reaction. This might be an advantage since it reduces the need of excess air for stack cooling, but has to be balanced as local cooling may cause high thermal gradients over the cell or stack area, which in turn might cause critical mechanical stresses.

Figure 4 shows a gas analysis when a fuel mixture of methane and steam was led to the SOFC. At the inlet, the mass spectrometer clearly shows the signals for methane (mass numbers 16 and 15). At the outlet, on the other hand, only hydrogen and CO were detected by the mass spectrometer (mass numbers 2 and 28, respectively). This result clearly confirms that methane steam reforming occurs under conditions of SOFC operation in the SOFC anode.
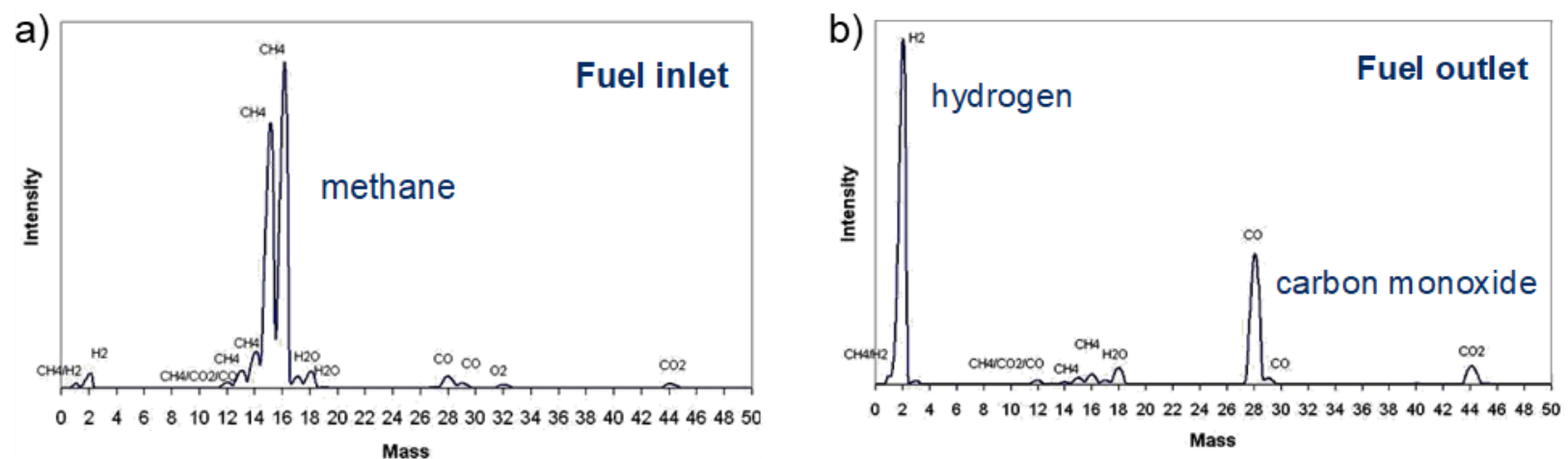

Figure 4 Mass spectrometer analysis of a methane containing fuel mixture before entering (inlet) and after leaving (outlet) the fuel cell at $850^{\circ} \mathrm{C}$, from [17]

Furthermore, also partial oxidation of methane (Equation 9) is considered as an option to avoid carbon formation, particularly for applications in the mobile sector, because the addition and on board storage of the reactant steam is not needed.

Equation 9 


\section{Theoretic electrical efficiencies}

The generally high electrical efficiencies of SOFC are an attractive advantage compared to combustion processes which are limited by the Carnot cycle, particularly in more and more electrified energy systems. For the alternative fuel examples ammonia and biogas it is thus interesting to calculate the maximum achievable electrical efficiencies and to compare them to other fuels like hydrogen and to other processes as combustion.

The maximum Carnot efficiency $\left(\eta_{\text {Carnot }}\right)$ of heat driven engines is defined as:

Equation 10

Where $T_{\text {hot }}$ and $T_{\text {cold }}$ are the operating temperatures of the high and low temperature reservoir, respectively.

The electrical efficiency of a fuel cell $\left(\eta_{F C}\right)$ is the electrical work (Gibbs free energy, $\Delta G$ ) divided by the energy content (enthalpy $\Delta H$ ) of the specific fuel:

Equation 11

The reaction enthalpy in this case is the heat of combustion. It can be expressed as higher heating value (HHV) - here the products of combustion are transferred to the original precombustion temperature, which can include condensation of gaseous products such as water. The lower heating value (LHV) considers all products in the gas phase, for example steam. Therefore, the energy required to vaporize liquid water is not released as heat.

For SOFC, efficiencies are typically related to the lower heating value. The heats of combustions are given by the specific fuel. The Gibbs free energy, on the other hand, is related to the actual electrochemical reaction species in the SOFC, which produce the electricity. As mentioned in the previous section, ammonia is decomposed to hydrogen and nitrogen and therefore, the actual SOFC reaction is Equation 3 and the related steam formation $\Delta G$ should be used for efficiency calculations.

The underlying equations and chemical reactions for calculating efficiencies are not always specified in the literature, which makes a fair comparison difficult if not impossible. In the present work, the applied considerations are therefore given in more detail. The change of the Gibbs free energy $\Delta G$ as related to the electrochemical SOFC reaction can be expressed as shown in Equation 12:

Equation 12 
$\Delta G^{o}$ is the change of the Gibbs free energy under standard conditions, $R$ is the universal gas constant, $T$ is the absolute temperature, $a$ is the activity of the corresponding reactant, and $v$ stoichiometry coefficients. As the stoichiometry coefficient is positive for the oxidation (ox) and negative for the reduction (red) of the redox reaction, Equation 12 can be simplified as shown in Equation 13. Additionally, as the activity of a molecule is quite difficult to determine, typically partial pressures $p_{i}$ are used instead as they are proportional to the activities.

Equation 13

$$
\Delta G=\Delta G^{\circ}+R T * \ln \left(\frac{p_{o x}}{p_{r e d}}\right)
$$

$\Delta G^{o}$ is determined from the difference between $\Delta G^{o}$ of the product and the reactant of the chemical reaction (seeEquation 14).

Equation 14

$$
\Delta G^{\circ}=\sum \Delta G_{o x}^{\circ}-\sum \Delta G_{r e d}^{\circ}
$$

The values for $\Delta G_{o x / \text { red }}^{\circ}$ were calculated using Equation 15 at the relevant temperature.

Equation 15

$$
\Delta G_{\text {ox } / \text { red }}^{\circ}=\Delta H_{o x / \text { red }}^{\circ}-T \Delta S_{\text {ox/red }}^{\circ}
$$

Assuming ideal gas behavior, $\Delta H^{o}$ and $\Delta S^{o}$ are calculated using Equation 16 and Equation 17.

Equation 16

$$
\Delta H^{\circ}=\int_{T_{0}}^{T} c_{p} d T
$$

Equation 17

$$
\Delta S^{\circ}=\int_{T_{0}}^{T} \frac{c_{p}}{T} d T
$$

Where $c_{p}$ is the specific heat capacity at constant pressure. The temperature dependence of $c_{p}$ can for example be expressed in terms of a $4^{\text {th }}$ order temperature-dependent polynomial. The coefficients of this polynomial are derived by numerical calculations as it is done by McBride et al. [36] .

The underlying reactions for the rection enthalpy of combustion $\Delta H$ in Equation 11 are for ammonia:

Equation 18

$$
\mathrm{NH}_{3}+\frac{3}{4} \mathrm{O}_{2} \rightarrow \frac{1}{2} \mathrm{~N}_{2}+\frac{3}{2} \mathrm{H}_{2} \mathrm{O}
$$

and for methane:

Equation 19

$$
\mathrm{CH}_{4}+2 \mathrm{O}_{2} \rightarrow \mathrm{CO}_{2}+2 \mathrm{H}_{2} \mathrm{O}
$$


For hydrogen fuel, Equation 3 is used.

For the Gibbs free energy $\Delta G$, the actual SOFC electrochemical reactions are important. As presented in the previous section, ammonia is decomposed to hydrogen and nitrogen (Equation 1) when entering the SOFC anode. Therefore, not ammonia, but hydrogen is the species, which is responsible for generating electricity and Equation 3 is used for efficiency calculations.

Fuelling the SOFC with natural gas or biogas, methane is first converted with steam and/or $\mathrm{CO}_{2}$ into hydrogen and $\mathrm{CO}$ with different possible ratios, which are in turn electrochemically oxidized in the SOFC anode. In order to calculate the theoretic possible electrical efficiency, methane is used for both $\Delta H$ (heat of combustion) and $\Delta G$ (electrical work). However, these efficiencies would only be achieved if methane is directly oxidized at the SOFC anode (direct methane fuel cell). This is not the case for SoA SOFC generations (as presented above), where hydrogen and $\mathrm{CO}$ from methane reforming reactions are oxidised, but it represents the limit when using methane containing fuel mixtures. Figure 5 shows the theoretic thermodynamic efficiencies of combustion engines (Carnot effienency calculated according to Equation 10) and SOFC (calculated according to Equation 11) using ammonia, natural gas, and hydrogen. As the curve for methane assumes that methane is the species which is electrochemically oxidised, the real values for methane containing fuels would lie between pure hydrogen and the methane curve. The values demonstrate that SOFC achieve higher efficviencies as compared to combustion engines. Furthermore, both, ammonia and methane (biogas) are hydrogen carriers which can provide high electrical efficiencies. They appear thus attractive over hydrogen fuel.

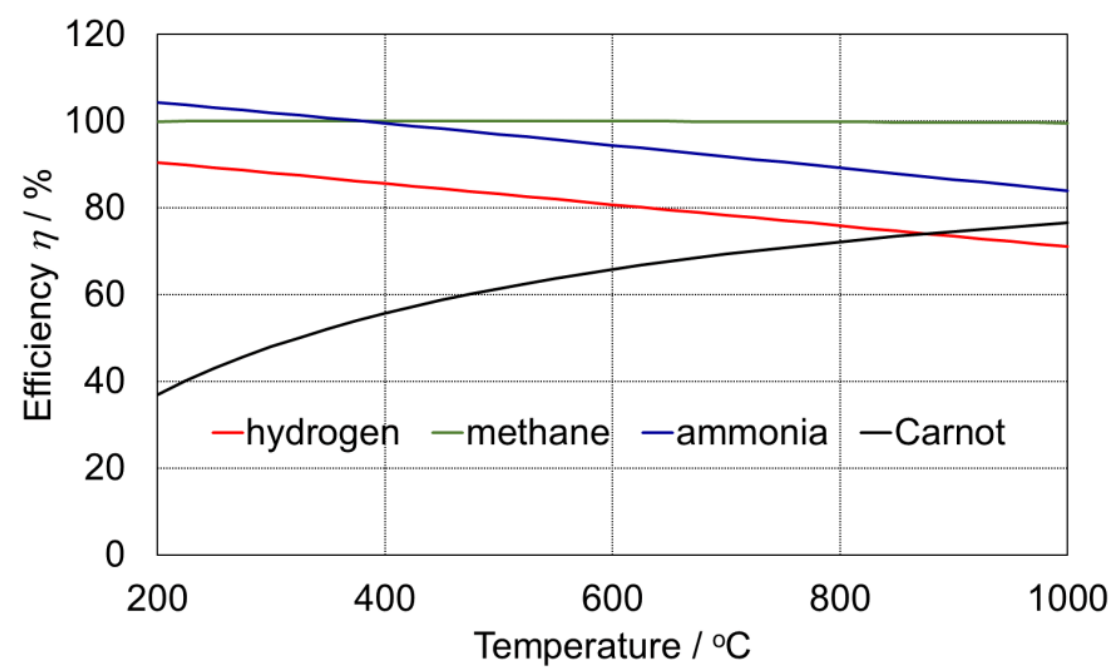

Figure 5 Theoretic efficiencies for combustion processes (Carnot, assuming $25{ }^{\circ} \mathrm{C}$ for the cold temperature $T_{\text {cold }}$ in Equation 10) and SOFC using different fuels as function of temperature (hydrogen (hydrogen oxidation), ammonia (hydrogen oxidation), and methane (methane oxidation)), using lower heating values for $\Delta H$ in Equation 11). 
These values underline the significant potential of SOFC. The practical efficiencies $\left(\eta_{F C}\right)$ will be lower as consequence of different losses in the SOFC. These losses are accounted for by including the voltage efficiency $\left(\eta_{U}\right)$ and current efficiency $\left(\eta_{I}\right)$ through Equation 20.

Equation 20

$$
\eta_{F C}=\eta_{I} \times \eta_{U}
$$

The work $\Delta G$ that is delivered by a fuel cell under ideal conditions is related to the voltage $E_{\text {rev }}$ through Equation 21.

Equation

$$
-\Delta G=U_{r e v} \cdot z \cdot F
$$

Where $\mathrm{z}$ is the number of electrons transferred in the fuel cell reaction and $F$ the Faraday constant.

The losses are calculated using Equation 22 for the voltage efficiency and Equation 23 for the current efficiency.

Equation

$$
\eta_{U}=\frac{U_{F C}}{U_{\text {rev }}}
$$

With the operating voltage $\left(U_{\mathrm{FC}}\right)$ and the theoretic voltage $\left(U_{\text {rev }}\right)$.

Equation

$$
\eta_{I}=\frac{I}{Z \cdot F \cdot n_{\text {fuel in }}}
$$

With the operating current $(I)$ and the added fuel flow $(n)$.

The practical electric efficiency of an operating SOFC can then be calculated according to Equation 24. This equation was used for calculating the electric efficiencies of the SOFC tests, which are presented in the forthcoming sections.

Equation 24

$$
\eta_{F C}=\frac{U_{F C} * I_{F C}}{n_{\text {fuel in }} * L H V_{f u e l}}
$$




\section{SOFC operation with alternative fuels}

\section{Experimental}

Two versions of anode supported, planar SOFCs were used for testing. Version (i) was based on a Ni/YSZ (yttria stabilized zirconia) anode support and active anode, a YSZ electrolyte, and a LSM/YSZ (lanthanum strontium manganite) cathode and version (ii) had the same half cell, a ceria gadolinia (CGO) barrier layer on top of the electrolyte, and a lanthanum strontium cobaltite ferrite (LSCF)/CGO cathode [37, 38].

Two versions of homemade alumina test houses were used as fixture for the cells (house version (a) for cell version (i) and house version (b) for cell version (ii), see Figure 6). Tests verified that both house versions deliver the same electrochemical performance and durability results. The cells with dimensions of $53 \times 53 \mathrm{~mm}^{2}$ and an active area of $16 \mathrm{~cm}^{2}$ were sandwiched between gas distribution and current collection layers. Air was provided at the cathode side and the specified fuels at the anode. Sealing was accomplished by glass ceramic seals. The test house was equipped with probes for measuring the cell voltage, current, temperature, and partial oxygen pressures of the incoming and outgoing fuel. The setups were described in detail in refs. [39, 35].

(a)

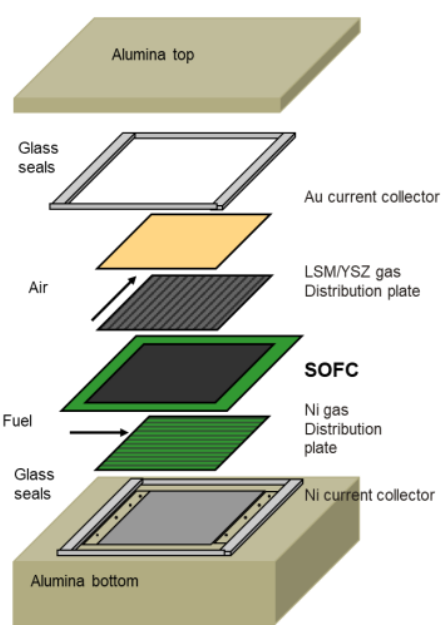

(b)

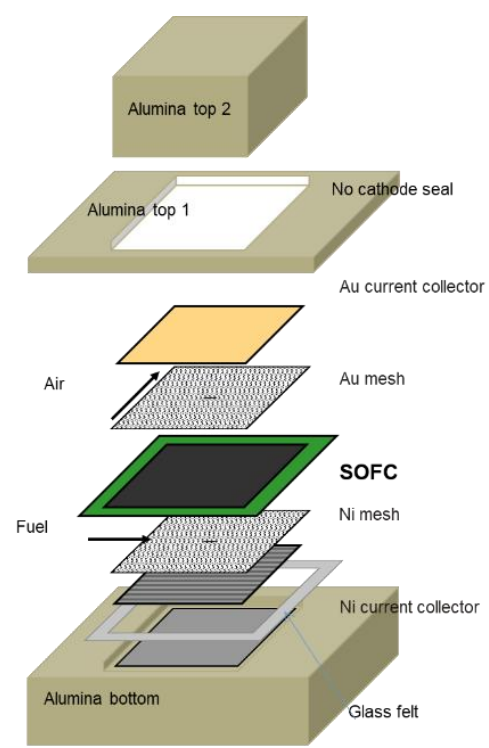

Figure 6 Homemade test house version (a) and version (b)

The test was initiated by sealing and anode reduction in diluted and then pure hydrogen at a temperature of $1000{ }^{\circ} \mathrm{C}$ (version (i)) or $850{ }^{\circ} \mathrm{C}$ (version (ii)). The initial performance was characterized using a standardized fingerprint protocol at OCV comprising of iV curves and electrochemical impedance spectroscopy (EIS) at different temperatures with variation of gas compositions to anode and cathode. More specifically, iV curves and EIS were recorded in air $(14 \mathrm{O} \mathrm{l} / \mathrm{h}$ ) to cathode and hydrogen $(10 \mathrm{l} / \mathrm{h})$ to the anode $(4 \%$ and $25 \%$ humidification), at 850,800 , and $750^{\circ} \mathrm{C}$. The purpose of this standard test protocol is to validate the test in terms of proper tightness of the setup and contacting of the cell and to validate the cell in terms of expected performance. Furthermore, it would allow for a 
detailed determination of resistance contributions from different SOFC components and reactions, which was beyond the scope of this study. Afterwards, durability test conditions were applied, i.e. the operating temperature was adjusted, the gas flows were regulated towards the target compositions, and initial iV curves and EIS were recorded under the specific conditions for the durability test (for specification, see the respective result sections).

\section{Test results-Ammonia fuel}

The use of ammonia as SOFC fuel was tested in direct comparison to fuelling a hydrogen to nitrogen mixture of 3:1. The initial electrochemical performance was measured by iV curves. The results are shown in Figure 7a. The results clearly demonstrate that ammonia provides the same power density as if hydrogen and nitrogen with the same ratio (3/1) are used. No additional resistances appear and thus the cracking of ammonia progresses as expected from Equation 1 and observed at OCV (see Figure 2).

The SOFC with a $53 \times 53 \mathrm{~mm}^{2}$ footprint was tested over 1500 hours at constant operating conditions at $850^{\circ} \mathrm{C}$ using ammonia fuel in order to assess durability (see Figure $7 \mathrm{~b}$ ). A reference test was carried out in a hydrogen $/ \mathrm{CO}_{2}$ mixture under otherwise the same conditions and on a similar cell version (see Figure $7 \mathrm{~b}$ ). The observed decrease of the power output with a larger rate in the first few hundred hours, followed by a levelling off towards $1000 \mathrm{~h}$ and beyond, is typical for this SOFC generation, both in the trend and the magnitude of ca. 2-4\%/1000 $\mathrm{h}$ [38]. No new, additional degradation as compared to using hydrogen containing fuel occurred. More recent SOFC generations are known to show better durability and thus more stable operation with ammonia fuel can be expected.

It has to be noted that the test conditions such as fuel utilisation were not adjusted to achieve the highest possible efficiencies, i.e. larger efficiencies than observed in the present ammonia tests are obtainable.
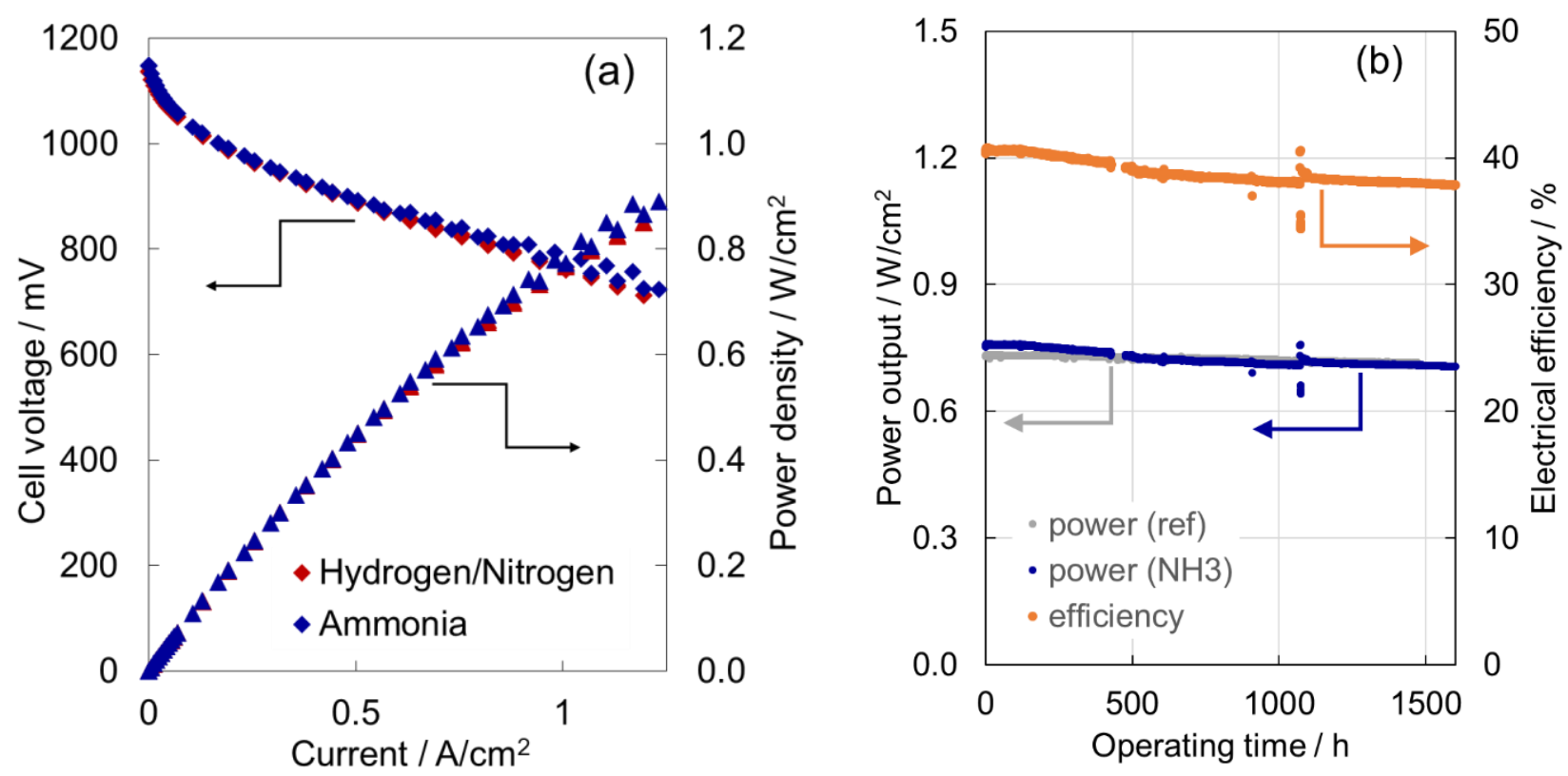
Figure 7 (a) Current-voltage and power output curves for the use of ammonia or a corresponding hydrogen/nitrogen mixture (3/1 ratio) as fuel at $850{ }^{\circ} \mathrm{C}$, recorded after the initial finger print and (b) Power output (blue curve) and efficiency (orange curve) calculated from the results according to Equation 24, during long-term test with ammonia fuel at $850^{\circ} \mathrm{C}, 1 \mathrm{~A} / \mathrm{cm}^{2}$ current density, data from [17], power output of reference test in hydrogen $/ \mathrm{CO}_{2}$ mixture (grey curve), SOFC version (i)

\section{Test results-Biogas fuel}

For the short-term biogas tests, representative compositions were selected as SOFC fuel and mixed from pure gasses: (i) landfill gas, which contains low amounts of methane and a biogas composition from processing of (ii) food waste (large amounts of methane) and (iii) from waste water treatment. The compositions are summarized in Table 3. Dependent on the amount of $\mathrm{CH}_{4}$ present in the biogas the amount of extra reforming agent - either steam or $\mathrm{CO}_{2}$ - was adjusted as to avoid carbon formation (see Figure 3). In addition, a real landfill gas was used in one test.

Table 3 Biogas compositions used for the test with SOFC and final applied fuel conditions

\begin{tabular}{|c|c|c|c|}
\hline \multirow[t]{2}{*}{ Biogas type } & \multirow{2}{*}{$\begin{array}{l}\text { Anode flow } \\
\text { rate }(1 / \mathbf{h})\end{array}$} & \multicolumn{2}{|l|}{ Anode gas composition } \\
\hline & & Biogas share (composition) & Reforming agent \\
\hline Food waste & 20 & 50 vol\% (70 vol\% $\mathrm{CH}_{4}, 30$ vol\% $\mathrm{CO}_{2}$ ) & 50 vol\% $\mathrm{H}_{2} \mathrm{O}$ \\
\hline Waste water & 20 & 60 vol\% (6o vol\% $\mathrm{CH}_{4}, 40$ vol\% $\mathrm{CO}_{2}$ ) & 40 vol\% $\mathrm{H}_{2} \mathrm{O}$ \\
\hline $\begin{array}{l}\text { Landfill gas } \\
\text { (pre-mixed) }\end{array}$ & 20 & $\begin{array}{l}77.5 \text { vol\% }\left(33 \text { vol\% } \mathrm{CH}_{4}, 33 \text { vol\% } \mathrm{CO}_{2} \text {, }\right. \\
\left.32 \text { vol } \% \mathrm{~N}_{2}\right)\end{array}$ & 22.5 vol\% $\mathrm{CO}_{2}$ \\
\hline $\begin{array}{l}\text { Landfill gas } \\
\text { (real) }\end{array}$ & 6 & $\begin{array}{l}67 \text { vol\% ( } 34 \text { vol\% } \mathrm{CH}_{4}, 23 \text { vol\% } \mathrm{CO}_{2}, 1.5 \\
\text { vol\% } \mathrm{O}_{2}, 41.5 \text { vol\% } \mathrm{N}_{2}\end{array}$ & 33 vol\% $\mathrm{CO}_{2}$ \\
\hline
\end{tabular}

After the initial fingerprint to validate a correct test setup and the cell performance, iV curves were recorded in the specific fuel compositions of interest in the current study.

In Figure 8, the measured iV curves and power output curves are shown when using premixed biogas compositions corresponding to either treatment of food waste (a) or waste water treatment (b). Measurements were recorded in biogas plus steam and biogas plus $\mathrm{CO}_{2}$. The same results were obtained when $\mathrm{CO}_{2}$ was used instead of steam as the reforming agent. The tests showed that such biogas can be successfully used as fuel and that both reforming strategies - steam and dry reforming - are possible options to achieve high performances while suppressing carbon formation. 

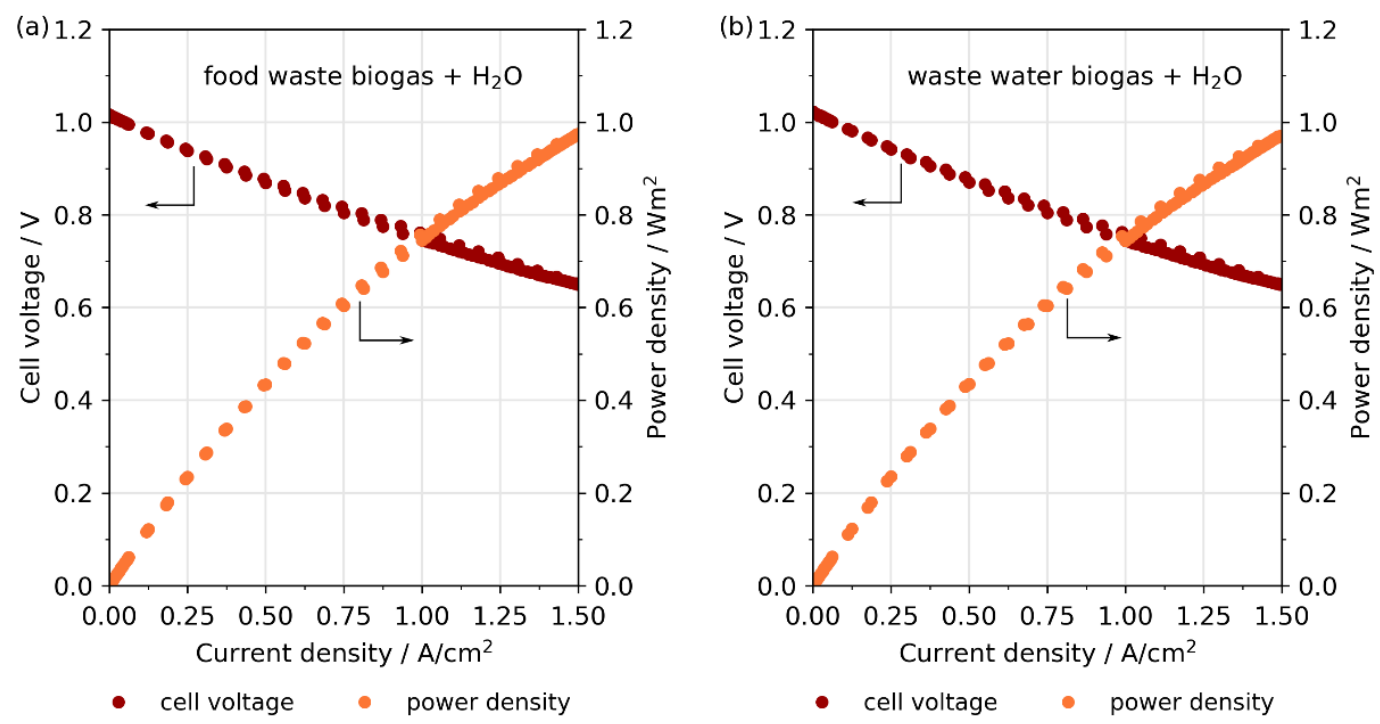

Figure 8 Current-voltage curves and power output measured on pre-mixed fuel compositions corresponding to biogas from food waste (a) or waste water treatment (b) with additional steam, $53 \times 53 \mathrm{~mm}^{2} \mathrm{SOFC}$ at $750^{\circ} \mathrm{C}, \mathrm{SOFC}$ version (ii)

The results when using landfill are shown in Figure 9. Here the example of dry reforming (addition of $\mathrm{CO}_{2}$ ) is shown in Figure 9a, using a pre-mixed biogas composition (see Table 3 ). The achievable power output is in a similar range as for the other types of biogas under otherwise similar conditions (such as temperature, fuel flow, etc.). A durability test with real landfill from the landfill location Odense Renovation using dry reforming is shown in Figure $9 \mathrm{~b}$. In order to provide controlled fuel conditions, the landfill was cleaned by sending it through an active carbon filter to remove any impurities before the SOFC. The power output was very constant over the testing time (degradation of only ca. $1 \% / 1000 \mathrm{~h}$ ) demonstrating the good stability of the current SOFC generation. Values of $47 \%$ electrical efficiency were demonstrated successfully over the full testing period; they are still away from the maximum achievable. 

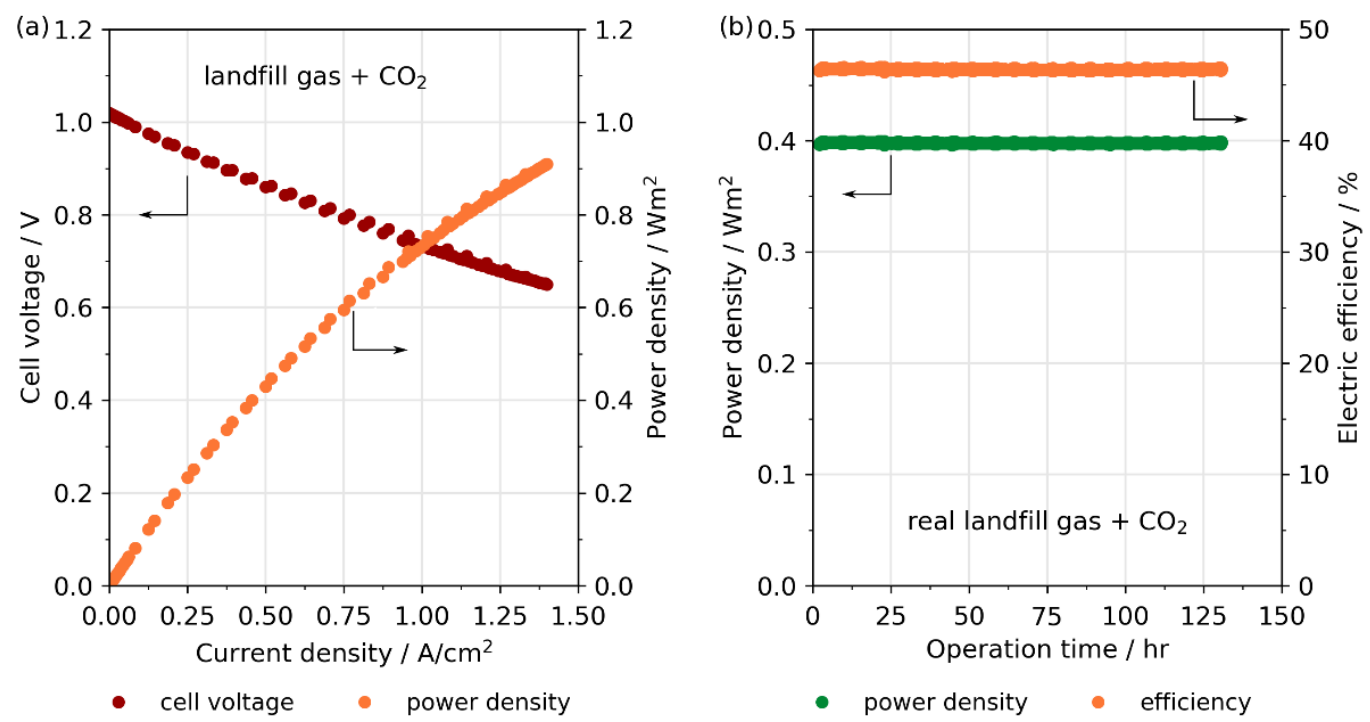

Figure 9 (a) Current-voltage and power output curves for the use of landfill (pre-mixed) and $\mathrm{CO}_{2}$ as fuel at $750{ }^{\circ} \mathrm{C}$, and (b) Power output and efficiency calculated from the results according to Equation 24, during long-term test with real landfill from Odense Renovation location and $\mathrm{CO}_{2}$ at $750^{\circ} \mathrm{C}, 0.5 \mathrm{~A} / \mathrm{cm}^{2}$ current density. The landfill was first sent through a cleaning unit containing active carbon, SOFC version (ii).

The results with landfill impressively demonstrate that the achievable performances and electrical efficiencies with SOFCs are not hampered by the presence of significant shares of nitrogen in the biogas (see Table 3, Figure 9). When the same fuel was to be used in combustion engines, such dilution may prevent completely the usability or require addition of extra fuel (like natural gas) or expensive engines (such as high pressure engines). The addition of the reforming agent $\mathrm{CO}_{2}$ might seem an obstacle at first sight, however, $\mathrm{CO}_{2}$ is also formed inside the SOFC during operation. This $\mathrm{CO}_{2}$ can be recycled into the SOFC gas inlet and no additional $\mathrm{CO}_{2}$ is required during operation. Such anode recycle was successfully demonstrated with real landfill at lab scale and will be presented elsewhere in detail.

\section{Conclusions}

Two alternative hydrogen carriers - ammonia and biogas - were presented. Ammonia has a long-term track-record of successful handling and distribution, worldwide. It can be directly used as fuel in state-of-the-art SOFCS, where it is cracked into hydrogen and nitrogen in the SOFC anode. The hydrogen is converted into steam producing electricity and heat. No local emissions of carbon dioxide occur. Toxic $\mathrm{NO}_{\mathrm{x}}$ are not formed under SOFC conditions. The obtainable electrical efficiencies are exceptionally high. The usability of ammonia as SOFC fuel was successfully demonstrated at lab scale and over 1500 hours of operation.

Biogas is a promising fuel of future fossil-free energy systems. Particularly, biogas from waste can be considered an important energy source. Different realistic biogas 
compositions from treatment of waste were used as fuel in an SOFC and shown to deliver high power densities and electrical efficiencies. The thermodynamic risk of carbon formation can be successfully counteracted by addition of steam or $\mathrm{CO}_{2}$ as reforming agents, where the reforming reaction occurs in state-of-the-art SOFC anodes. The biogas from landfills is particularly challenging because of its natural dilution with nitrogen, which often prevents energetic use in conventional combustion engines. The tests with an SOFC verified, that landfill gas is a valuable fuel for SOFCs, which can deliver high electrical efficiencies. The concept was demonstrated at lab scale over a period of ca. $130 \mathrm{~h}$ using real landfill gas.

\section{Acknowledgement}

The authors express their greatest thanks to Ulrik Lønkjær and Rasmus Olsen from Odense Renovation for providing the opportunities of using real landfill gas, Nils Hintzen and Ole Hansen for technical support in collecting landfill gas, and Henrik Henriksen for technical support at DTU Energy. Financial support by VESTAS for data analysis is gratefully acknowledged.

\section{Symbols \& Abbreviations}

$a_{i}$ : Activity of a reactant $i$

$c_{p:}$ Specific heat capacity at constant pressure $[\mathrm{J} / \mathrm{K}]$

$F$ : Faraday constant $[\mathrm{C} / \mathrm{mol}]$

FC: Fuel cell

FU: Fuel utilisation

HHV: Higher heating value of the fuel cell fuel $[\mathrm{J} / \mathrm{kg}][\mathrm{J} / \mathrm{L}]\left[\mathrm{J} / \mathrm{mol} \mathrm{s}^{-1}\right]$

$I_{\mathrm{FC}}$ : Current in the fuel cell [A]

LHV: Lower heating value of the fuel cell fuel $[\mathrm{J} / \mathrm{kg}][\mathrm{J} / \mathrm{L}]\left[\mathrm{J} / \mathrm{mol} \mathrm{s}^{-1}\right]$

$n_{\text {fuel: }}$ Molar flow of the fuel entering the fuel cell [mol s-1]

OCV: Open circuit voltage

$p_{i}$ : Partial pressure of a reactant $i$

$R$ : Universal gas constant $\left[\mathrm{J} / \mathrm{molK}^{-1}\right]$

$T:$ Temperature [K]

$U_{\mathrm{FC}}$ : Voltage [V]

$\eta$ : Efficiency 
$\Delta G$ : Gibbs free energy $[\mathrm{J} / \mathrm{mol}]$

$\Delta H$ : Reaction enthalpy of combustion $[\mathrm{J} / \mathrm{mol}]$

$v_{i}$ : Stoichiometry coefficient of component $i$

$\Delta \mathrm{S}$ : Reaction entropy $\left[\mathrm{J} / \mathrm{molK}^{-1}\right]$

z: Number of electrons transferred in the fuel cell reaction

\section{References}

1 D. Stolten, R. Can Samsun, N. Garland (Editors), Fuel Cells: Data, Facts and Figures, (978-3-527-33240-3) WILEY-VCH, 2016.

2 I. Staffell, D. Scamman, A. Velazquez Abad, P. Balcombe, P. E. Dodds, P. Ekins, N. Shah, K. R. Ward, The role of hydrogen and fuel cells in the global energy system, Energy \& Environmental Science, DOI: 10.1039/c8ee01157e.

3 J.D. Holladay, J. Hu, D.L. King, Y. Wang, An overview of hydrogen production technologies, Catal. Today 139 (2009) 244-260.

4 J. Watson, Y. Zhang, B. Si, W.-T. Chen, R. de Souza, Gasification of biowaste: A critical review and outlooks, Renewable and Sustainable Energy Reviews 83 (2018) 1-17, https://doi.org/10.1016/j.rser.2017.10.003.

5 EU 2030 Energy Strategy https://ec.europa.eu/energy/en/topics/energy-strategy-andenergy-union/2030-energy-strategy, visited April 2019.

6 FUEL CELLS and HYDROGEN 2 JOINT UNDERTAKING (FCH 2 JU) 2019 ANNUAL WORK PLAN and BUDGET NOTICE, https://www.fch.europa.eu/sites/default/files/FCH\%202\%20JE\%20Annual\%20Work\%2 oPlan\%20and\%20Budget\%202019\%20(ID\%205167414).pdf, visited April 2019

7 Japanese group unveils SOFC Ene-Farm residential cogen unit, Fuel Cells Bulletin 2012(4) 4, doi.org/10.1016/S1464-2859(12)70093-7. enefarm, ene.field, pace, bloom energy

8 S. J. McPhail, J. Kiviaho, B., THE YELLOW PAGES OF SOFC TECHNOLOGY International Status of SOFC deployment 2017, IEA Implementing Agreement Advanced Fuel Cells Annex 32 - SOFC, ISBN 978-951-38-8602-8 (printed); ISBN 978-951-38-86035 (online) (2017).

9 J. Rostrup Nielsen, Catalytic Steam Reforming, Springer Verlag 1984.

10 J. Sehested, Catal. Today, 111 (1-2) (2006) 103-110. 
11 R. Peters, R. Dahl, U. Klüttgen, C. Palm, D. Stolten, Internal reforming of methane in solid oxide fuel cell systems, J. Power Sources 106 (2002) 238-244.

12 D. Mogensen, J.-D. Grunwaldt, P.V. Hendriksen, J.U. Nielsen, K. Dam-Johansen, Methane Steam Reforming over an Ni-YSZ Solid Oxide Fuel Cell Anode in Stack Configuration, J. Chemistry (2014) 1-8, http://dx.doi.org/10.1155/2014/710391.

13 V. Chiodo, A. Galvagno, A. Lanzini, D. Papurello, F. Urbani, M. Santarelli, S. Freni, Biogas reforming process investigation for SOFC application, Energy Conversion and Management 98 (2015) 252-258.

14 Y. Shiratori, T. Ijichi, T. Oshima, K. Sasaki, Internal reforming SOFC running on biogas, Int. J. Hydrogen Energy 32 (2010) 7905-7912.

15 A. Hagen, A. Winiwarter, H. Langnickel, G. Johnson, SOFC operation with real biogas, Fuel Cells 17(6) (2017) 854-861.

16 G.B. Johnson, P. Hjalmarsson, K. Norrman, U.S. Ozkan, A.Hagen, Fuel Cells 2016, 16(2), 219.

17 A. Hagen, Use of Alternative Fuels in Solid Oxide Fuel Cells, Risø International Energy Conference 2007, 2007, Risø-R-1608(EN).

18 N. Dekker and B. Rietveld, Highly Efficient Conversion of Ammonia in Electricity by Solid Oxide Fuel Cells, Proceedings of and presented during the 6th European Solid Oxide Fuel Cell Forum 28 June - 2 July 2004, page 1524 Lucerne / Switserland.

19 K. Eguchi, Y. Takahashi, H. Yamasaki, H. Kubo, A. Okabe, T. Isomura, T. Matsuo, Development of Ammonia-fueled Solid Oxide Fuel Cell Systems, Proceedings 13th EFCF Lucerne 2018, ISBN 978-3-905592-23-8, Chapter o7 - Session A15, 13-18.

20 B. Stoeckl, V. Subotić, M. Preininger, M. Schwaiger, N. Klopcic, H. Schroettner, C. Hochenauer, Large planar SOFC MEA operation with ammonia: Experimental analysis and performance evaluation, Proceedings 13th EFCF Lucerne 2018, ISBN 978-3-90559223-8, Chapter 07 - Session A15, 69-76.

21 C.H. Christensen, R. Zink Sørensen, T. Johannessen, U.J. Quaade, K. Honkala, T.D. Elmøe, R. Køhler, J.K. Nørskov, J. Mater. Chem., 15 (2005) $4106-4108$.

22 N. Kumar Agnihotra, Ammonia Production by Haldor Topsøe Conventional Technology, PEP Review 2016-14, IHS Chemical (2016).

23 R. Lan and S. Tao, Frontiers in Energy Research, August 2014, Volume 2, Article 35, 14. doi: 10.3389/fenrg.2014.00035

24 P. H. Pfromm, Towards sustainable agriculture: Fossil-free ammonia, J. Renewable Sustainable Energy 9 (2017) 034702-1 - 11, https://doi.org/10.1063/1.4985090. 
25 K. E. Lamb, M. D. Dolan, D. F. Kennedy, Ammonia for hydrogen storage; A review of catalytic ammonia decomposition and hydrogen separation and purification, International Journal of Hydrogen Energy 44(7) (2019) 3580-3595.

26 http://en.wikipedia.org/wiki/Energy_density, assessed February 2019.

27 C.W. Bale, E. Bélisle, P. Chartrand, S.A. Decterov, G. Eriksson, A.E. Gheribi, K. Hack, I.H. Jung, Y.B. Kang, J. Melançon, A.D. Pelton, S. Petersen, C. Robelin, J. Sangster, P. Spencer, M-A. Van Ende, FactSage thermochemical software and databases, 2010-2016, https://doi.org/10.1016/j.calphad.2016.05.002

28 R. Lan, J. T. S. Irvine, S. Tao, Ammonia and related chemicals as potential indirect hydrogen storage materials, International Journal of Hydrogen Energy 37(7) (2012) 14821494 .

29 EurObserv'ER: Biogas Barometer 2017. In: EurObserv'ER (Hrsg.), https://www.eurobserv-er.org/biogas-barometer-2017/, accessed November 2018.

30 N. Scarlat, J.-F. Dallemand, F. Fahl, Biogas: Developments and perspectives in Europe, Renewable Energy 129 (2018) 457-472.

31 B. Kampman, C. Leguijt, T. Scholten (CE Delft), J. Tallat-Kelpsaite, R. Brückmann, G. Maroulis (Eclareon), J.P. Lesschen, K. Meesters, N. Sikirica, B. Elbersen (Wageningen Research), EU report: Optimal use of biogas from waste streams, An assessment of the potential of biogas from digestion in the EU beyond 2020, December 2016.

32 B. Tjaden, M. Gandiglio, A. Lanzini, M. Santarelli, M. Järvinen, Small-Scale BiogasSOFC Plant: Technical Analysis and Assessment of Different Fuel Reforming Options. Energy \& Fuels 28 (2014) 4216-4232.

33 M.MosayebNezhad, A.S.Mehr, M.Gandiglio, A.Lanzini, M.Santarelli, Techno-economic assessment of biogas-fed CHP hybrid systems in a real wastewater treatment plant, Applied Thermal Engineering 129 (2018) 1263-1280.

34 G.B. Johnson, P. Hjalmarsson, K. Norrman, U.S. Ozkan, A.Hagen, Fuel Cells 2016, $16(2), 219$.

35 A. Hagen, A. Winiwarter, H. Langnickel, G. Johnson, SOFC operation with real biogas, Fuel Cells 17(6) (2017) 854-861.

36 B.J. McBride, S. Gordon and M.A. Reno 'Coefficients for Calculating Thermodynamic and Transport Properties of Individual Species', NASA Report TM-4513, October 1993.

37 N. Christiansen, J. B. Hansen, H. Holm-Larsen, M.J. Jørgensen, L. Theil Kuhn, P. V. Hendriksen, A. Hagen and S. Linderoth, Solid Oxide Fuel Cell Research and Development at Topsoe Fuel Cell A/S and Risø/DTU, Proceedings of the 8th European Solid Oxide Fuel Cell Forum, Lucerne, Switzerland (2008). 
38 A. Hagen, R. Barfod, P.V. Hendriksen, Y.-L. Liu, S.Ramousse, Degradation of anode supported SOFCs as a function of temperature and current load, J. Electrochem. Soc. 153(6) (2006) A1165

39 M. Mogensen, and Peter Vang Hendriksen, in High Temperature Solid Oxide Fuel Cells. Fundamentals, Design, and Applications, S. C. Singhal, K. Kendall, Editors, Chapt. 10, Elsevier, New York (2003). 